\title{
Manajemen Data Standar Pelayanan Minimal Rumah Sakit
}

\section{The Hospital Minimum Service Standard Data Management}

\author{
Sigid Nugroho Adhi ${ }^{1}$ \\ Kori Puspita Ningsih ${ }^{2}$ \\ 1,2)Program Studi Rekam Medis dan Informasi Kesehatan \\ Fakultas Kesehatan Universitas Jenderal Achmad Yani Yogyakarta \\ Jl.Brawijaya, Ringroad Barat Ambarketawang, Gamping, Sleman ${ }^{1-2}$ \\ E-mail: hanyasigid@gmail.com ${ }^{1}$,puspitakori@gmail.com ${ }^{2}$
}

\begin{abstract}
Hospitals as Regional Public Service Bodies (BLUDs) must make and submit documents as administrative requirements, one of which is the Minimum Service Standards (MSS). Therefore, the hospital is required to show its accountability by always meeting the MSS. The purpose of this study was to determine the Hospital Minimum Service Standard data management,. To describe the management of MSS data, the researchers used a descriptive type of research with a qualitative approach. They are collecting data in this study by observation and interviews with the Head of the Nursing and Quality Division and 21 quality coordinators in each unit of the Panembahan Senopati Bantul Hospital. Researchers maintain the validity of qualitative data by using triangulation techniques. The results of the study show that the regulations governing the implementation of the MSS RSUD Panembahan Senopati Bantul refer to (Bantul Regent Regulation Number 74 of 2017 concerning Guidelines for Financial Management of Regional Public Service Bodies (BLUD) at Panembahan Senopati Hospital Bantul, 2017). The flow of data collection for RSSMS went through a relatively long stage, involving 21 unit quality coordinators to be reported to the Quality Section and Clinical Audit. Furthermore, the Head of the Quality and Clinical Audit Section will present the SPM data for the unit into the RS SPM report. RS SPM data processing is still done conventionally using the Ms. program. Excel. MSS data is reported to the Top Management and then to the Regent of Bantul along with the hospital performance reports every semester and annually no later than two months after the reporting period ends. There are $32 \%$ ( 8 of 21 services) that reach the standard indicator. Utilization of hospital SPM data to fulfill statutory requirements, customer requirements, BLUD requirements, service quality measurements according to the SNARS PMKP chapter, and as a benchmark for hospital performance.
\end{abstract}

Keywords: data management; minimum service standards; hospitals

\begin{abstract}
Abstrak
Rumah sakit sebagai Badan layanan Umum Daerah (BLUD) mempunyai kewajiban membuat dan menyampaikan dokumen sebagai syarat administrasi, yang salah satu adalah Standar Pelayanan Minimal (SPM). Oleh karena itu, rumah sakit dituntut untuk menunjukkan akuntabilitasnya dengan senantiasa memenuhi SPM RS. Tujuan penelitian ini untuk mengetahui manajemen data Standar Pelayanan Minimal Rumah Sakit (SPM RS) di RSUD Panembahan Senopati Bantul. Untuk dapat mendiskripsikan manajemen data SPM RS, maka peneliti menggunakan jenis penelitian deskriptif dengan pendekatan kualitatif. Pengumpulan data pada penelitian ini dengan observasi dan wawancara kepada Kepala Bidang Keperawatan dan Mutu, dan 21 koordinator mutu di masing-masing unit RSUD Panembahan Senopati
\end{abstract}


Bantul. Untuk menjaga validitas penelitian kualitatif, maka dilakukan metode triangulasi sumber, teknik dan waktu. Hasil penelitian menunjukkan regulasi yang mengatur implementasi SPM RS di RSUD Panembahan Senopati Bantul mengacu pada (Peraturan Bupati Bantul Nomor 74 Tahun 2017 Tentang Pedoman Pengelolaan Keuangan Badan Layanan Umum Daerah (BLUD) di RSUD Panembahan Senopati Bantul, 2017). Alur perolehan data SPM RS melalui tahap yang cukup panjang, dengan melibatkan 21 koordinator mutu unit untuk dilaporkan kepada kepada Seksi Mutu dan Audit Klinik. Selanjutnya Kepala Seksi Mutu dan Audit klinik akan menyajikan data SPM unit tersebut menjadi laporan SPM RS. Pengolahan data SPM RS masih dilakukan secara konvensional dengan menggunakan program Ms. Excel. Data SPM RS dilaporkan kepada Top Manajemen untuk selanjutnya disampaikan ke Bupati Bantul bersamaan dengan laporan kinerja rumah sakit setiap semester dan tahunan paling lambat 2 bulan setelah periode pelaporan berakhir. Terdapat $32 \%$ (8 dari 21 pelayanan) yang mencapai satandar indikator. Pemanfaatan data SPM RS untuk memenuhi persyaratan perUndangan, persyaratan pelanggan, persayaratan BLUD, pengukuran mutu pelayanan sesuai pada SNARS bab PMKP dan sebagai tolak ukur kinerja rumah sakit.

Kata kunci: manajemen data; standar pelayanan minimal; rumah sakit

\section{Pendahuluan}

Rumah sakit sebagai Badan layanan Umum Daerah (BLUD) mempunyai kewajiban membuat dan menyampaikan dokumen sebagai syarat administrasi, salah satunya adalah Standar Pelayanan Minimal (SPM) (Peraturan Menteri Dalam Negeri No 61 tahun 2007 tentang Pedoman Teknis Pengelolaan Keuangan adan layanan Umum Daerah, 2007). SPM merupakan ketentuan tentang jenis dan mutu pelayanan dasar urusan wajib daerah yang berhak diperoleh setiap warga negara secara minimal (Permenkes

RI Nomor:129/Menkes/SK/II/2008, 2008). SPM juga digunakan sebagai tolok ukur pengukuran mutu pelayanan rumah sakit (KARS, 2017). Indikator SPM RS tersebut merupakan suatu tolak ukur pencapaian prestasi yang dinilai secara kuantitatif maupun kualitatif, dengan tujuan memberikan gambaran pencapaian sasaran indikator SPM tertentu, yang meliputi input, proses, output maupun outcome dari pelayanan tertentu. Oleh karena itu, rumah sakit dituntut untuk menunjukkan akuntabilitasnya dengan senantiasa memenuhi SPM RS (Kori Puspita Ningsih etal, 2019).

Hasil penelitian (Supriyanto et al., 2014) tentang analisa faktor-faktor penyebab tidak lengkapnya laporan SPM RS di Rumah Sakit Muhammadiyah Ahmad Dahlan Kota Kediri, menunjukkan bahwa kelengkapan laporan standar pelayanan minimal rumah sakit tidak berjalan dengan baik dikarenakan pergantian tim mutu, tidak lengkapnya anggota sehingga menyebabkan tidak berjalannya program peningkatan mutu berkelanjutan dengan pencapaian SPM. Berdasarkan hasil survey awal di RSUD Panembahan Senopati Bantul, diketahui bahwa program peningkatan mutu berkelanjutan melalui monitoring SPM RS telah berjalan. Laporan SPM RS dibuat setiap semester dan dilaporkan bersamaan dengan laporan kinerja RS kepada Bupati Bantul.

RSUD Panembahan Senopati Bantul sudah menggunakan sistem informasi manajemen rumah sakit, tetapi belum dapat menyajikan kebutuhan output laporan SPM RS, sehingga pengelolaan data SPM RS masih dilakukan secara konvensional, sehingga membutuhkan tahapan alur pelaporan yang cukup panjang dan membutuhkan waktu yang lama. Adanya data yang heterogen juga menjadi kendala pada kelengkapan dan ketepatan pengumpulan laporan SPM dari unit kerja.

Tujuan penelitian ini untuk mengetahui manajemen data Standar Pelayanan Minimal 
Rumah Sakit (SPM RS) yang meliputi: (1) regulasi internal yang mengatur implementasi SPM RS; (2) alur perolehan data SPM RS; (3) pengolahan data SPM RS; (4) pelaporan SPM RS; (5) pemanfaatan laporan SPM RS.

\section{Metode}

Untuk dapat mendiskripsikan manajemen data SPM RS, maka peneliti menggunakan jenis penelitian deskriptif dengan pendekatan kualitatif (Prof.Dr.Sugiyono, 2014). Pengumpulan data pada penelitian ini dengan observasi dan wawancara kepada Kepala Bidang Keperawatan dan Mutu, dan 21 koordinator mutu di masing-masin unit RSUD Panembahan Senopati Bantul. Dari hasil wawancara tersebut akan diperoleh data primer mengenai regulasi internal yang mengatur implementasi SPM RS, alur perolehan data SPM RS, pengolahan data SPM RS, pelaporan SPM RS dan pemanfaatan laporan SPM RS. Data sekunder dihimpun melalui Kebijakan, Surat Keputusan Standar Prosedur Operasional (SPO), laporan-laporan SPM RS yang diperoleh dengan cara review dokumen.

Untuk menjaga validitas penelitian kualitatif, maka dilakukan metode triangulasi sumber, teknik dan waktu. Peneliti akan melakukan triangulasi sumber yaitu dengan mencocokkan informasi hasil wawancara seluruh informan dengan informasi dari informan triangulasi yaitu Kepala Seksi Mutu dan Audit Klinik dan Dewan Pengawas RS Kabupaten Bantul. Triangulasi teknik dengan cara membandingkan hasil wawancara, hasil observasi dan studi dokumentasi. Selanjutnya setelah seluruh data terkumpul, peneliti melakukan analisis data menggunakan analisis isi (content analysis), yaitu untuk menganalisis data kualitatif yang diperoleh dari hasil wawancara mendalam, observasi dan studi dokumentasi. Analisis isi adalah suatu metode yang digunakan untuk menganalisis komunikasi secara sistematik, obyektif terhadap pesan yang terlihat. Data dipilih menurut relevansinya, selanjutnya data disajikan dalam bentuk narasi

\section{Hasil dan Pembahasan}

a. Regulasi Yang Mengatur Implementasi SPM RS

Regulasi yang mengatur implementasi SPM RS di RSUD Panembahan Senopati Bantul mengacu pada (Peraturan Bupati Bantul Nomor 74 Tahun 2017 Tentang Pedoman Pengelolaan Keuangan Badan Layanan Umum Daerah (BLUD) di RSUD Panembahan Senopati Bantul, 2017). Pada pedoman tersebut disampaikan bahwa SPM RS merupakan satu diantara lampiran laporan kinerja yang wajib dilaporkan oleh RSUD Panembahan Senopati Bantul kepada Bupati Bantul setiap semester dan tahunan paling lambat 2 bulan setelah periode pelaporan berakhir.

RSUD Panembahan Senopati Bantul menjalankan 21 indikator SPM RS disusun mengacu pada (Peraturan Menteri Kesehatan Republik Indonesia nomor: 129/Menkes/SK/II/2008 Tentang Standar Pelayanan Minimal Rumah Sakit, 2008) yang meliputi: (1) Pelayanan gawat darurat; (2) Pelayanan rawat jalan: (3) Pelayanan rawat inap; (4) Pelayanan bedah; (5) Pelayanan persalinan dan perinatology; (6) Pelayanan intensif; (7) Pelayanan radiologi; (8) Pelayanan laboratorium patologi klinik; (9) Pelayanan rehabilitasi medik; (10) Pelayanan farmasi, (11) Pelayanan gizi, (12) Pelayanan transfusi darah; (13) Pelayanan keluarga miskin, (14) Pelayanan rekam medis, (16) Pengelolaan limbah; (17) Pelayanan administrasi manajemen; (18) Pelayanan ambulans/kereta jenazah; (19) Pelayanan laundry; (20) Pelayanan pemeliharaan sarana rumah; (21) Pencegah Pengendalian Infeksi. Dalam hal pengorganisasian tugas dan fungsi, RSUD Panembahan Senopati Bantul mengacu pada (Peraturan Bupati Bantul Nomor 147 Tahun 2016 Tentang Kedudukan, Susunan Organisasi, Tugas dan Fungsi, Serta Tata Kerja RSUD Panembahan Senopati kabupaten Bantul, 2016), yang mana penanggungjawab utama penyusunan rencana SPM, penyelenggaraan monitoring 
dan evaluasi pencapaian SPM adalah Kepala Seksi Mutu dan Audit Klinik.

Dalam hal teknis kegiatan, RSUD Panembahan Senopati Bantul belum memiliki Standar Operasional Prosedur (SPO) pelaporan SPM RS. SPO merupakan hal yang sangat penting, karena SPO merupakan serangkaian intruksi tertulis yang dibakukan untuk menjelaskan proses penyelenggaraan administrasi pemerintahan, bagaimana, kapan, dimana dan oleh siapa dilakukan (Rara Sabrina Dukma dan Siswati, 2017).

b. Alur Perolehan Data SPM RS

Alur perolehan data SPM RS di RSUD Panembahan Senopati Bantul sebagai berikut:

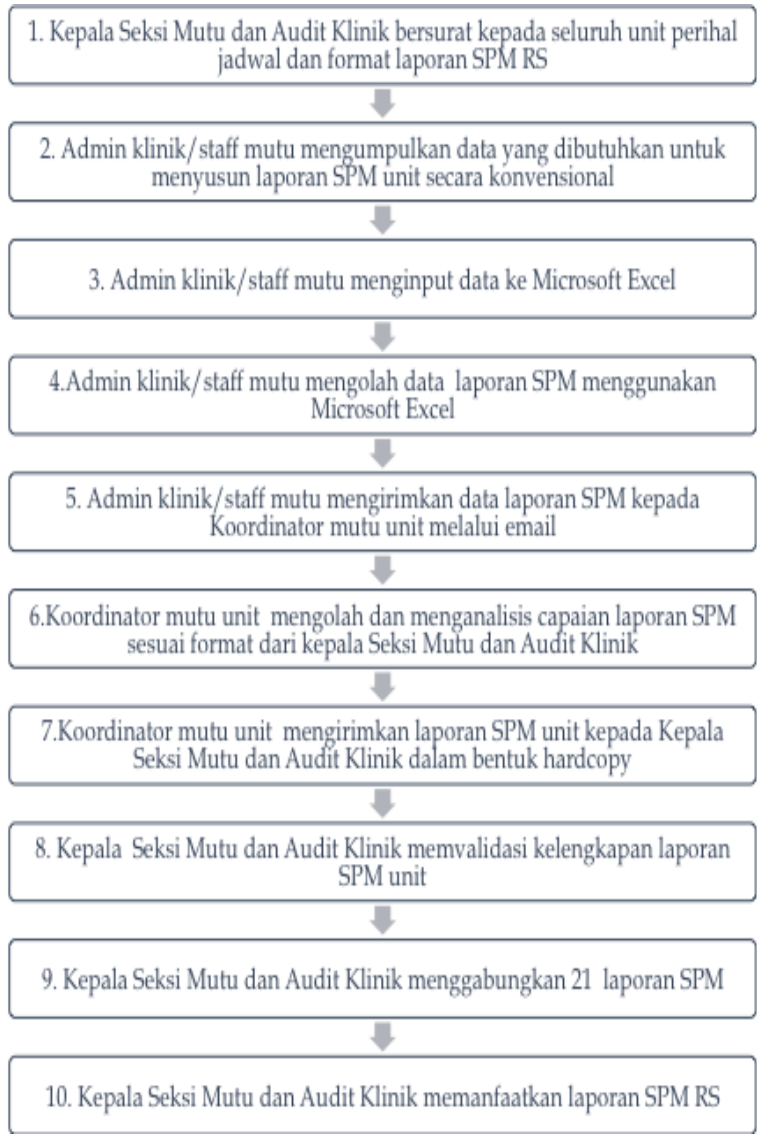

\section{Gambar 1. Alur perolehan data SPM RS}

Berdasarkan gambar 1 dapat disampaikan bahwa Kepala Seksi Mutu dan Audit Klinik memperoleh data laporan SPM RS dari kegiatan collecting atau pengumpulan data dari 21 unit. Pada setiap periode pelaporan Kepala Seksi Mutu dan Audit Klinik bersurat ke 21 unit untuk menyampaikan jadwal dan format laporan SPM RS. Koordinator mutu unit dibantu oleh admin klinik/staff mutu mengumpulkan data melalui formulir, buku register di masing-masing unit sesuai kebutuhan laporan SPM unit. Selanjutnya dilakukan input data menggunakan program MS Excel. Adanya dublikasi pencatatan tersebut menyebabkan petugas membutuhkan waktu lama dalam pengumpulan data, banyak tempat/media dalam penyimpanan data, dan kesulitan dalam pencarian data. Hal ini menunjukkan sistem yang saat ini berjalan belum efisien dan informasi yang belum tepat waktu. Kelemahan dan kelayakan dari sebuah sistem dapat dinilai dari adanya ketepatan waktu untuk menghasilkan informasi (timeliness), yaitu sistem yang ada harus dapat menghasilkan dan mengirimkan informasi yang cepat dan tepat (Hakam, 2016).

Koordinator mutu mengolah data dari admin klinik/ staff mutu sesuai format dan menganalisis capaian SPM. Saat ini Kepala Seksi Mutu dan Audit Klinik belum mendokumentasikan waktu pengiriman laporan SPM dari 21 unit kepada Kepala Seksi Mutu dan Audit Klinik. Apabila ada keterlambatan maka Kepala Seksi Mutu dan Audit Klinik menghubungi secara perlisan untuk memenuhi pengiriman laporan SPM, dan apabila sampai 3 kali masih belum mengirimkan, maka akan di hubungi oleh Kepala Bidang Keperawatan dan Mutu.

Kepala Seksi Mutu dan Audit Klinik memvalidasi kelengkapan laporan SPM unit, dan digabungkan menjadi laporan SPM RS yang mencakup 21 unit pelayanan, untuk selanjutnya, informasi dari laporan SPM RS tersebut dimanfaatkan oleh Kepala Seksi Mutu dan Audit Klinik. Informasi dapat berguna tergantung kepada kualitas informasi yang dihasilkan, informasi akan berguna apabila kualitasnya baik. Satu diantara syarat kualitas informasi yang baik adalah adanya kelengkapan (completeness) informasi, yaitu cukup tidaknya informasi 
jika digunakan sebagai bahan untuk membuat keputusan (Hutahean, 2014).

Kelengkapan laporan SPM RS di RSUD Panembahan Senopati Bantul masih terbatas pada ada tidaknya laporan yang dikirim. Karena dalam hal pengumpulan laporan tidak semua pelayanan melampirkan sumber data sebagai bukti pencapaian indikator. Informasi akan memiliki nilai semakin sempurna jika kebenaran informasi tersebut dapat dibuktikan. Kebenaran informasi bergantung pada validitas data sumber yang diolah (Palit et al., 2015).

\section{c. Pengolahan Data SPM RS}

Pengolahan data SPM RS di RSUD Panembahasn Senopati Bantul masih dilakukan secara konvensional, dengan pengolahan menggunakan program Ms Excel dan melalui tahapan proses yang cukup panjang (gambar 1). Pengolahan data secara konvensional tersebut juga memiliki banyak kelemahan, yaitu waktu yang lama untuk menghasilkan informasi, keakuratan yang kurang dapat di terima karena berpotensi terjadinya kesalahan dalam menghasilkan informasi. Penyimpanan data dan informasi dalam softcopy dalam program Ms. Excel dan formulir serta laporan berbentuk kertas di berbagai tempat berdampak terjadinya kesulitan pada saat pencarian data kembali dan rentan terjadinya kehilangan data dan informasi (Kori Puspita Ningsih etal, 2019). Pengembangan sistem informasi diperlukan untuk mengatasi permasalahan tersebut. Sistem informasi dapat meningkatkan proses organisasi. Sistem informasi mengotomatiskan banyak tahap pada proses-proses yang ada di organisasi yang sebelumnya dilakukan secara konvensional dan menghasilkan informasi yang cepat dan tepat (Firman et al., 2016).

\section{d. Pelaporan SPM RS}

Data SPM RS di RSUD Panembahan Senopati Bantul dilaporkan setiap semester kepada:

1) Internal
Laporan SPM RS yang sudah disusun oleh Kepala Seksi Mutu dan Audit Klinik dikirimkan kepada Kepala Bidang Keperawatan dan Mutu. Selanjutnya Kepala Bidang Keperawatan dan Mutu akan menyampaikan laporan SPM RS kepada Wakil Direktur pelayanan dan penunjang, Wakil Direktur Umum dan Keuangan, Bidang Pelayanan Medis, Bidang Penunjang, Bagian Pengembangan, Bagian keuangan dan Bagian Umum. Selain untuk kepentingan Top Manajemen, laporan SPM RS juga diguankan oleh Tim PMKP untuk nukti adminitrasi pemenuhan bab PMKP 6 SNARS.

Dari hasil studi dokumentasi menunjukkan laporan SPM RS Semester I tahun 2019 dikirimkan tanggal 22 Juli 2019, sedangkan Semester II pada 24 Januari 2020. Hal ini menunjukkan laporan SPM RS dikirimkan tepat waktu. Hal ini dipertegas pada (Pedoman Teknis Pengelolaan Keuangan Badan Layanan Umum Daerah, 2007) bahwa laporan kinerja paling lambat dikumpulkan 2 (dua) bulan setelah periode pelaporan berakhir

2) Eksternal

Direktur akan menyampaikan laporan SPM RS kepada Bupati Bantul melalui Dewan Pengawas RS. Dalam hal pengawasan, Gubernur/ Bupati/ walikota mengawasi penyelenggaraan pelayanan kesehatan sesuai SPM RS di daerah masing-masing (Permenkes RI Nomor:129/Menkes/SK/II/2008, 2008).

e. Laporan SPM RS Tahun 2019

Pada laporan SPM RS di RSUD Panembahan Senoapti bantul terdapat 110 indikator (tabel 1). Hal ini mengacu pada 
(Permenkes

Nomor:129/Menkes/SK/II/2008, 2008) dan (Peraturan Bupati Bantul Nomor 74 Tahun 2017 Tentang Pedoman Pengelolaan Keuangan Badan Layanan Umum Daerah (BLUD) di RSUD Panembahan Senopati Bantul, 2017).

Tabel 1. Indikator SPM RS

\begin{tabular}{|c|c|c|c|c|}
\hline \multirow{2}{*}{ No } & \multirow{2}{*}{ Jenis Pelayanan } & \multirow{2}{*}{$\begin{array}{l}\text { Jumlah } \\
\text { Indikator }\end{array}$} & \multicolumn{2}{|c|}{ Indikator Tercapai } \\
\hline & & & Semester I & Semester II \\
\hline 1 & IGD & 8 & 5 & 5 \\
\hline 2 & Rawat Jalan & 10 & 8 & 8 \\
\hline 3 & Rawat Inap & 16 & 12 & 12 \\
\hline 4 & Bedah Sentral & 7 & 6 & 5 \\
\hline 5 & $\begin{array}{l}\text { Persalinan Perinatal dan } \\
\text { KB }\end{array}$ & 14 & 12 & 12 \\
\hline 6 & Intensif & 3 & 2 & 2 \\
\hline 7 & Radiologi & 4 & 3 & 3 \\
\hline 8 & $\begin{array}{l}\text { Laboratorium patologi } \\
\text { Klinik }\end{array}$ & 4 & 4 & 4 \\
\hline 9 & Rehabilitasi medis & 3 & 3 & 3 \\
\hline 10 & Farmasi & 5 & 2 & 3 \\
\hline 11 & Gizi & 3 & 3 & 3 \\
\hline 12 & Transfusi Darah & 2 & 1 & 1 \\
\hline 13 & Pelayanan gakin & 1 & 1 & 1 \\
\hline 14 & Rekam medis & 4 & 2 & 2 \\
\hline 15 & Pengelolaan Limbah & 5 & 5 & 5 \\
\hline 16 & Administrasi & 9 & 7 & 6 \\
\hline 17 & Ambulance & 3 & 3 & 3 \\
\hline 18 & Pemulasaran Jenazah & 1 & 1 & 1 \\
\hline 19 & $\begin{array}{l}\text { Pelayanan Pemeliharaan } \\
\text { Sarana Rumah Sakit }\end{array}$ & 3 & 1 & 1 \\
\hline 20 & Laundry & 2 & 1 & 1 \\
\hline 21 & PPI & 3 & 3 & 3 \\
\hline
\end{tabular}

Pada tahun 2019 terdapat 32\% pelayanan (8 dari 21 jenis pelayanan) yang mencapai sandar indikator SPM (gambar 2).

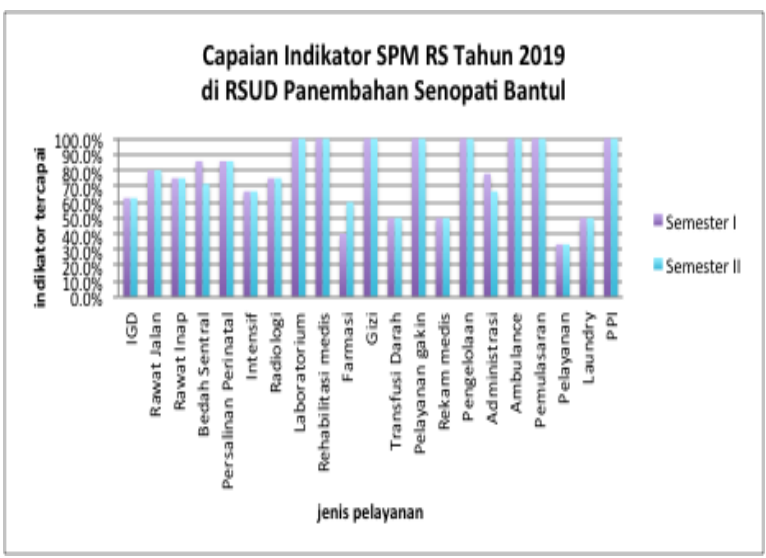

Gambar 2. Capaian Indikator SPM RS Tahun 2019
Berdasarkan gambar 2 dapat disampaikan bahwa 8 jenis pelayanan yang sudah mencapai standar $100 \%$ meliputi (1) pelayanan laboratorium patologi klinik; (2) rehabilitasi medis; (3) Gizi; (4) pelayanan gakin; (5) Pengeolaan limbah; (6) Ambulance; (7) Pemulasaran jenazah; (8) PPI.

Untuk pelayanan belum mencapai standar indikator maka koordinator mutu unit menyusun rencana tindaklanjut perbaikan mutu menggunakan Siklus PDCA (Plan Do Check Action) dalam upaya mencapai standar SPM. Penyusunan rencana tindak lanjut merupakan bentuk kegiatan evaluasi yang telah dilakukan oleh unit pelayanan di RSUD Panembahan Senopati Bantul dan diperlukan oleh Top Manajemen sebagai bagian dari dari siklus manajemen pada tahap pengawasan. Fungsi pengawasan mempunyai kaitan erat dengan fungsi perencanaan, pengorganisasian dan pelaksanaan. Melalui fungsi pengawasan standar keberhasilan program yang telah dibuat dalam bentuk target dapat dibandingkan dengan hasil yang telah dicapai. Jika ada penyimpangan yang terjadi harus segera diatasi, dideteksi secara dini, dicegah, dikendalikan atau dikurangi oleh Pimpinan (Susetyo Herlambang \& Arita Murwani, 2012).

f. Pemanfaatan data SPM RS.

Data SPM RS RSUD Panembahan Senopati Bantul dimafaatkan untuk:

1) Persyaratan perUndangan

Data SPM RS yang sudah merupakan salah satu bentuk upaya RSUD Panembahan Senopati Bantul dalam memenuhi persyaratan hak setiap warna negara untuk memperoleh pelayanan kesehatan seperti yang tertuang pada Undang - Undang Dasar Negara Republik Indonesia Tahun 1945.

2) Persyaratan Pelanggan

Data SPM RS merupakan hasil pengukuran kinerja pelayanan yang sudah diaktualisasikan oleh seluruh 
unit pelayanan RSUD Panembahan Senopati Bantul dalam mendukung kepuasan pasien. Melalui proses penilaian capaian indikator SPM yang terukur diharapkan dapat menggambarkan suatu penilaian kegiatan pelayanan yang dinilai sesuai standar yang ditetapkan dalam SPM. Kepuasan pasien menjadi salah satu indikator yang digunakan sebagai pencitraan awal rumah sakit apakah rumah sakit tersebut memberikan pelayanan yang baik bagi pelanggannya (Sriatmi et al., 2014). Upaya untuk meningkatkan kepuasan bahkan kesetiaan pelanggan dan menjamin keamanan pasien dapat dilakukan dengan standarisasi pelayanan. Standar pelayanan tersebut perlu ditunjukkan dengan fakta. Oleh akrena itu pengkuran indikator dan target pencapaian tiap indikator perlu disusun, disepakati dan ditetapkan sebagai acuan (Kuntjoro et all, 2007).

3) Persayaratan administrasi Badan layanan Umum Daerah (BLUD)

Peran RSUD Panembahan Senopati Bantul sebagai BLUD menuntut rumah sakit untuk memnuhi syarat adminitrasi sebagai BLUD. Hal ini dipertegas pada (Pedoman Teknis Pengelolaan Keuangan Badan Layanan Umum Daerah, 2007) yang menjelaskan bahwa BLUD-SKPD wajib menyusun dan menyampaikan laporan keuangan lengkap yang terdiri dari laporan operasional, neraca, laporan arus kas dan catatan atas laporan keuangan disertai laporan kinerja kepada PPKD untuk dikonsolidasikan ke dalam laporan keuangan pemerintah daerah.

4) Pemenuhan Bab Peningkatan Mutu dan Keselamatan Pasien (PMKP) pada Standar Nasional Akreditasi Rumah Sakit (SNARS)
Adanya data SPM RS sebagai tolok ukur pengukuran mutu pelayanan RSUD Panembahan Senopati Bantul juga didukung oleh Standar Nasional Akreditasi Rumah Sakit (SNARS) pada standar Peningkatan Mutu dan Keselamatan Pasien (PMKP) 6 yang menjelaskan bahwa setiap unit kerja di RS memilih dan menetapkan indikator mutu yang dipergunakan untuk mengukur mutu unit kerja. Indikator mutu unit kerja tersebut dapat menggunakan indikator mutu yang tercantum di dalam Standar Pelayanan Minimal (SPM) (KARS, 2018).

5) Tolak ukur kinerja rumah sakit Informasi capaian SPM RS digunakan oleh Top Manajemen sebagai bahan pengukuran kinerja bidang pelayanan masing-masing unit kerja. Standar Pelayanan Minimal Bidang Kesehatan Kabupaten/Kota (SPM-BK) merupakan tolak ukur kinerja pelayanan kesehatan yang diselenggarakan daerah kabupaten/kota (Hendarwanl \& Oster, 2014)

Pemerintah melakukan pengawasan melalui Gubernur/Bupati/Walikota dalam penyelenggaraan pelayanan kesehatan sesuai standar pelayanan minimal rumah sakit di masingmasing daerah (Peraturan Menteri Kesehatan Republik Indonesia nomor : $\quad$ 129/Menkes/SK/II/2008 Tentang Standar Pelayanan Minimal Rumah Sakit, 2008). Akan tetepi RSUD panembahan Senopati Bantul tidak menerima umpan balik atas laporan SPM RS yang sudah disampaikan kepada Bupati Bantul melalui dewan pengawas rumah 
sakit. Evaluasi terhadap implementasi SPM di rumah sakit hanya berupa laporan saja dan jarang ada umpan balik dari pihak yang berkaitan. Padahal jika tidak ada umpan balik dari rendahnya pencapaian SPM RS maka dapat berpengaruh pada kualitas pelayanan rumah sakit (Kuzairi et al., 2017).

\section{Simpulan dan Saran}

Regulasi yang mengatur implementasi SPM RS di RSUD Panembahan Senopati Bantul mengacu pada (Peraturan Bupati Bantul Nomor 74 Tahun 2017 Tentang Pedoman Pengelolaan Keuangan Badan Layanan Umum Daerah (BLUD) di RSUD Panembahan Senopati Bantul, 2017). Alur perolehan data SPM RS melalui tahap yang cukup panjang, dengan melibatkan 21 koordinator mutu unit untuk dilaporkan kepada kepada Seksi Mutu dan Audit Klinik. Selanjutnya Kepala Seksi Mutu dan Audit klinik akan menyajikan data SPM unit tersebut menjadi laporan SPM RS.

Pengolahan data SPM RS masih dilakukan secara konvensional dengan menggunakan program Ms. Excel. Data SPM RS dilaporkan kepada Top Manajemen dan Tim PMKP serta kepada Bupati Bantul bersamaan dengan laporan kinerja rumah sakit setiap semester dan tahunan paling lambat 2 bulan setelah periode pelaporan berakhir. Pemanfaatan data SPM RS untuk memenuhi persyaratan perUndangan, persyaratan pelanggan, persayaratan BLUD, pengukuran mutu peayanan sesuai pada SNARS bab PMKP dan sebagai tolak ukur kinerja rumah sakit.

\section{Ucapan Terima Kasih}

Terima kasih disampaikan kepada Kemenristekdikti yang telah mendanai keberlangsungan penelitian ini.

\section{Daftar Pustaka}

Firman, A., Wowor, H. F., Najoan, X., Teknik, J., Fakultas, E., \& Unsrat, T. (2016).
Sistem Informasi Perpustakaan Online Berbasis Web. Jurnal Teknik Elektro Dan Komputer, 5(2), 29-36. https://doi.org/10.35793/jtek.5.2.2016.1 1657

Hakam, F. (2016). Analisis, Perancangan dan Evaluasi Sistem Informasi Kesehatan. Gosyen Publishing.

Hendarwanl, H., \& Oster, R. (2014). Analisis Implementasi Standar Pelayanan Minimal Bidang Kesehatan Kabupaten / Kota. Jurnal Ekologi Kesehatan, Vol.14 No., 367-380.

Hutahean, J. (2014). Summary for Policymakers. In Climate Change 2013 The Physical Science Basis (Vol. 53, Issue 9). Deepublish. https://doi.org/10.1017/CBO978110741 5324.004

KARS. (2018). Standar Nasional Akreditasi Rumah Sakit Edisi 1 (1st ed., pp. 1-421). KARS.

https://doi.org/10.15713/ins.mmj.3

Peraturan Menteri Dalam Negeri No 61 tahun 2007 tentang Pedoman Teknis Pengelolaan Keuangan adan layanan Umum Daerah, 1 (2007).

Permenkes RI

Nomor:129/Menkes/SK/II/2008, 1 (2008).

Peraturan Menteri Kesehatan Republik Indonesia nomor : 129/Menkes/SK/II/2008 Tentang Standar Pelayanan Minimal Rumah Sakit, Nomor Tambahan Lembaran Negara Nomor 4355 Nomor Tambahan Lembaran Negara Nomor 4400 (2008). https://doi.org/10.1017/CBO978110741 5324.004

Kori Puspita Ningsih etal. (2019). Pengembangan Pelaporan Standar Pelayanan Minimal Gawat Darurat Berbasis Web. Jurnal Kesehatan 
Vokasional, 4(4), 201-208. https:// doi.org/10.22146/jkesvo.49165

Kuntjoro et all. (2007). Standar Pelayanan Minimal Rumah Sakit Sebagai Persyaratan BLUD. Jurnal Managemen Pelayanan Kesehatan, 10(01 Maret), 0310.

Kuzairi, U., Yuswadi, H., Budiharjo, A., \& Patriadi, H. B. (2017). Implementasi Standar Pelayanan Minimal (SPM) Pada Pelayanan Publik Bidang Pelayanan Kesehatan (Studi Kasus Pada Rumah Sakit Umum Dr. H. Koesnadi Bondowoso). Politico, 17(2), 184-205. https://doi.org/10.32528/POLITICO.V1 $7 \mathrm{I} 2.881$

Pedoman Teknis Pengelolaan Keuangan Badan Layanan Umum Daerah, 1 (2007).

Palit, R. V, Rindengan, Y. D. Y., \& Lumenta, A. S. M. (2015). Rancangan Sistem Informasi Keuangan Berbasis Web Di Jemaat GMIM Bukit Moria Malalayang. E-Journal Teknik Elektro Dan Komputer Vol, 4(7), 1-7.

Peraturan Bupati Bantul Nomor 147 Tahun 2016 Tentang Kedudukan, Susunan Organisasi, Tugas dan Fungsi, Serta Tata Kerja RSUD Panembahan Senopati kabupaten Bantul, (2016).

Peraturan Bupati Bantul Nomor 74 Tahun 2017 Tentang Pedoman Pengelolaan Keuangan Badan Layanan Umum Daerah (BLUD) di RSUD Panembahan Senopati Bantul, (2017).

Rara Sabrina Dukma dan Siswati. (2017). Tinjauan Pelaksanaan Standar Prosedur Operasional Distribusi Rekam Medis Rawat Jalan Di Rumah Sakit Umum Daerah Kota Bekasi. Jurna INOHIM, 5(2), 125-129.

Sriatmi, A., Suryawati, C., \& Hidayati, A. (2014). Analisis Hubungan Karakteristik Pasien Dengan Kepuasan Pelayanan Rawat Jalan Semarang Eye Center (Sec)
Rumah Sakit Islam Sultan Agung Semarang. Jurnal Kesehatan Masyarakat (e-Journal), 2(1), 9-14.

Supriyanto, E., Hariyanti, T., \& Widayanti Lestari, E. (2014). Analisa Faktor-faktor Penyebab Tidak Lengkapnya Laporan Standar Pelayanan Minimal Rumah Sakit di Rumah Sakit Muhammadiyah Ahmad Dahlan Kota Kediri. Jurnal Kedokteran Brawijaya, 28(1), 36-40. https://doi.org/10.21776/ub.jkb.2014.02 8.01 .20

Susetyo Herlambang \& Arita Murwani. (2012). Cara Mudah Mempelajari Manajemen Kesehatan dan Rumah Sakit. Gosyen Publishing. 
